\title{
A Study on the Several Characteristics and Applications of Whale and Sperm Oils, Polymerized by Silent Electric Discharge*
}

\author{
Masao Gotoda**
}

The preceding report $^{1)}$ dealt with the research on the silent discharge polymerization (Voltolization) reaction of Whale and Sperm oils (both brain and skin) and discussed the reaction process and the changes in these oils involved with polymerization in a comparative study. As its sequence the author carried out several tests on the characteristics of the polymerized products and their applications.

(1) High vacuum distillation of voltolized Sperm oil.

Sperm oil, when subjected to mere polymerization by discharge, is supposed to contain considerable amounts of monomers. To what extent the viscosity of such oil when its monomer contents have been eliminated through high vacuum distillation, has been tested. Fractions up to $200^{\circ} \mathrm{C}$ were removed under high vacuum about $10^{-3} \mathrm{~mm} \mathrm{Hg}$ from samples (A) No. 6, (B) No. 5 and 6 (see Table 1 in previous report). As the results, low acid value, high viscosity oils were gained, no gelation having taken place thereby.

Table 1

\begin{tabular}{|c|c|c|c|c|c|c|c|c|c|}
\hline $\begin{array}{l}\text { Samp. } \\
\text { No. }\end{array}$ & $\begin{array}{l}\text { Materials for } \\
\text { distillation* }\end{array}$ & & $\begin{array}{r}\text { Visc } \\
\text { Temp. }\end{array}$ & ty & $\begin{array}{c}\text { Intrinsic Vis. } \\
{[\eta] \times 10^{2}} \\
25^{\circ} \mathrm{C}\end{array}$ & $\begin{array}{l}\text { Iodine } \\
\text { value }\end{array}$ & $\begin{array}{c}\text { Acid } \\
\text { value }\end{array}$ & Yield \% & $\begin{array}{c}\text { Mol. } \\
\text { Weights }\end{array}$ \\
\hline 1 & $\begin{array}{c}\text { Voltolized } \\
\text { Sperm skin oil } \\
\text { No. } 5\end{array}$ & $\begin{array}{l}\text { original oil } \\
\text { distillate } \\
\text { residue }\end{array}$ & $\begin{array}{l}100^{\circ} \mathrm{F} \\
\left\{\begin{array}{l}100^{\circ} \mathrm{F} \\
210^{\circ} \mathrm{F}\end{array}\right.\end{array}$ & $\begin{array}{r}37.3 \\
84.3 \\
5.9\end{array}$ & $\begin{array}{l}11.0 \\
- \\
13.7\end{array}$ & $\begin{array}{l}87.5 \\
75.0 \\
83.6\end{array}$ & $\begin{array}{r}4.2 \\
16.0 \\
2.5\end{array}$ & $\begin{array}{r}0 \\
31 \\
69\end{array}$ & $\begin{array}{l}1090 \\
- \\
1905\end{array}$ \\
\hline 2 & $\begin{array}{l}\text { Voltolized } \\
\text { Sperm skin oil } \\
\text { No. } 6\end{array}$ & $\begin{array}{l}\text { original oil } \\
\text { distillate } \\
\text { residue }\end{array}$ & $\begin{array}{c}100^{\circ} \mathrm{F} \\
- \\
\left\{\begin{array}{l}100^{\circ} \mathrm{F} \\
210^{\circ} \mathrm{F}\end{array}\right.\end{array}$ & $\begin{array}{r}72.0 \\
- \\
102.0 \\
5.5\end{array}$ & $\begin{array}{l}12.2 \\
- \\
15.0\end{array}$ & $\begin{array}{l}89.3 \\
71.6 \\
67.6\end{array}$ & $\begin{array}{r}* * \\
19.1 \\
2.7\end{array}$ & $\begin{array}{r}0 \\
24 \\
76\end{array}$ & 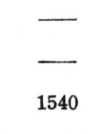 \\
\hline 3 & $\begin{array}{l}\text { Voltolized } \\
\text { Sperm brain }\end{array}$ & $\begin{array}{l}\text { original oil } \\
\text { distillate } \\
\text { residue }\end{array}$ & $\left\{\begin{array}{l}100^{\circ} \mathrm{F} \\
\overline{100^{\circ} \mathrm{F}} \\
178^{\circ} \mathrm{F} \\
210^{\circ} \mathrm{F}\end{array}\right.$ & $\begin{array}{c}32.3 \\
\\
\text { sticky } \\
123.5 \\
85.0\end{array}$ & $\begin{array}{l}10.6 \\
- \\
-\end{array}$ & $\begin{array}{l}76.0 \\
60.9 \\
48.3\end{array}$ & $\begin{array}{r}5.0 \\
24.0 \\
2.8\end{array}$ & $\begin{array}{r}0 \\
48 \\
52\end{array}$ & $\begin{array}{l}1110 \\
- \\
2500\end{array}$ \\
\hline 4 & No. 5 & $\begin{array}{l}\text { original oil } \\
\text { distillate } \\
\text { residue }\end{array}$ & $\begin{array}{l}210^{\circ} \mathrm{F} \\
- \\
100^{\circ} \mathrm{F}\end{array}$ & $\begin{array}{l}32.3 \\
- \\
45.0\end{array}$ & 10.6 & $\begin{array}{l}76.0 \\
52.0 \\
74.5\end{array}$ & $\begin{array}{r}5.0 \\
16.5 \\
3.2\end{array}$ & $\begin{array}{r}0 \\
20 \\
80\end{array}$ & $\begin{array}{l}1110 \\
- \\
1910\end{array}$ \\
\hline
\end{tabular}

* Sample Nos. of these materials denote that of those in Table 1 of the preceding report.

** This value is estimated about equal to that of voltolized Sperm skin oil No. 5 .

(2) Application of Voltolized Sperm oil as plasticizer.

In recent years, so-called high polymer plasticizers, for example, polyesters, have come to be used to impart improved cold resistance to P.V.C. resins. In order to check the validity of such plasticizers for that purpose, part of the D.O.P. in the D.O.P. plasticized P.V.C. was replaced by the earliermentioned vacuum distillated voltolized Sperm oil (Sample No. 1 in Table 1) and the resulting film was measured for the change in mechanical properties. For the measurement, tensile tests, using K.S. type Senimeter, were carried out at $25 \sim-40^{\circ} \mathrm{C}$ on filament specimens prepared from a thin film that had been made by the Solvent method developed by $\mathrm{Tsuji}^{2)}$ and $\mathrm{Murai}^{3)}$; in these tests temperature change

* Studies on the Polymerization of Oils by Silent Electric Discharge (Part 4).

** Railway Technical Research Institute (Japan National Railways), Kokubunji, Tokyo, Japan The original written in Japanese can be seen in J.Electrochem. Soc. Japan 643 (1959). 
Table 2 Tensile Test Results of the Plastisized PVC Resin.

\begin{tabular}{|c|c|c|c|c|c|c|c|c|c|c|c|c|}
\hline \multirow{3}{*}{$\begin{array}{c}\text { Sample } \\
\text { No. }\end{array}$} & \multirow{2}{*}{\multicolumn{3}{|c|}{ Composition }} & \multicolumn{4}{|c|}{ Tensile strength $\left(\mathrm{kg} / \mathrm{cm}^{2}\right)$} & \multirow{3}{*}{$\begin{array}{c}\text { Cold } \\
\text { proofness }\end{array}$} & \multirow{2}{*}{\multicolumn{4}{|c|}{$\begin{array}{c}\text { Elongation }(\%) \\
\text { Temp. }{ }^{\circ} \mathrm{C}\end{array}$}} \\
\hline & & & & \multicolumn{4}{|c|}{ Temp. ${ }^{\circ} \mathrm{C}$} & & & & & \\
\hline & \multicolumn{2}{|c|}{ P.V.C : D.O.P : } & $\begin{array}{c}\text { Voltolized } \\
\text { oil }\end{array}$ & 25 & 5 & -15 & -40 & & 25 & 5 & -15 & -40 \\
\hline 1 & 10 & 2 & 0 & 284 & 346 & 479 & 631 & 5.4 & 166 & 20 & 13 & 10 \\
\hline 2 & 10 & 3 & 0 & 229 & 312 & 389 & 460 & 3.5 & 228 & 21 & 29 & 12 \\
\hline 3 & 10 & 2 & 1 & 169 & 263 & 322 & 380 & 3.1 & 36 & 12 & 6 & 6 \\
\hline 4 & 10 & 1 & 2 & 183 & 273 & 316 & 450 & 3.9 & 9 & 5 & 5 & 4 \\
\hline 5 & 10 & 4 & 0 & 175 & 238 & 290 & 350 & 2.6 & 291 & 75 & 40 & 23 \\
\hline
\end{tabular}

* Cold proofness $=\sum_{i} t_{i} \sum_{i} X_{i}-n \sum_{i} t_{i} X_{i} /\left(\sum t_{i}\right)^{2}-n \sum_{i} t_{i}{ }^{2}\left(\mathrm{~kg} / \mathrm{cm}^{2} l^{\circ} \mathrm{C}\right), \quad t_{i}=$ temp. $X_{i}=$ Tensile strength at $t_{i}$.

was also investigated. The results are given by Table 2 and Fig. 1, and the values of cold proofness listed in the Table are given in terms of the increase of tensile strength of the sample film versus temerature decrease According to these values, it is clear that a considerable decrease of ductility occurs through replacement of D.O.P. with voltolized sperm oil; strength, too, falls but not to the same extent as ductility; and there is no large variance in cold resistance. On the whole it can be stated that they might be used as compounding agent so long as such decrease in ductility is allowable.

(3) Usefulness as lubricant additives.

The effectiveness of each voltolized Whale oil when it was added to diesel-engine oil was checked for the purpose of ascertaining its characteristics (mainly with respect to increase of viscosity, increase of viscosity index, and pour point depressing) as lubricant additive; for the measurement of melting point, Levin and others' microanalytical method ${ }^{4}$ was adopted.

Table 3 lists the results of $5 \%$ additions of vacuum distillated voltolized Sperm oil (Table 1, No. 1) to paraffin base, naphthene base, and mixed base dieselengine oils respectively.

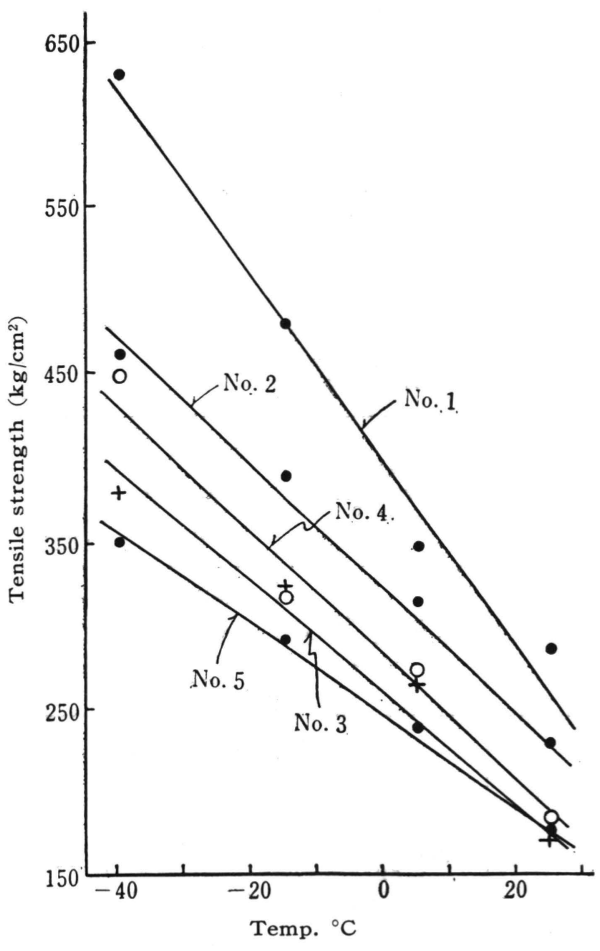

Fig. 1 Change of tensile strength with temp. for plastisized P.V.C. films.

Table 3 Addition Effect of Voltolized Sperm oil to Diesel Engine Oil

\begin{tabular}{|c|c|c|c|c|c|}
\hline \multirow{2}{*}{ Diesel engine oil composition } & \multirow{2}{*}{$\begin{array}{c}\text { Addition } \\
\%\end{array}$} & \multicolumn{2}{|c|}{ Viscosity cps } & \multirow{2}{*}{ Vis. Index } & \multirow{2}{*}{$\begin{array}{c}\text { Ponr Point } \\
{ }^{\circ} \mathrm{C}\end{array}$} \\
\hline & & $100^{\circ} \mathrm{F}$ & $210^{\circ} \mathrm{F}$ & & \\
\hline \multirow{2}{*}{ Paraffinic base } & 0 & 140.9 & 11.3 & 64.0 & -14.0 \\
\hline & 5 & 200.0 & 15.6 & 84.5 & -14.5 \\
\hline \multirow{2}{*}{ Mixed base } & 0 & 127.8 & 9.8 & 40.0 & -26.0 \\
\hline & 5 & 181.0 & 13.5 & 69.0 & -27.0 \\
\hline \multirow{2}{*}{ Napthenic base } & 0 & 151.6 & 9.9 & 9.9 & -23.0 \\
\hline & 5 & 228.4 & 14.7 & 55.3 & -26.0 \\
\hline
\end{tabular}

Effectiveness was manifest, though to different extents depending on the base oil, but no effects on the pour point depression were established. 
Table 4 represents the results of $10 \%$ additions of Sample No. 5 of Sperm oil in Table 1 and sample No. 5 of Whale oil in Table 1 to naphthene base diesel-engine oil; it is revealed that there is no great change in charcteristics related to viscosity.

Table 4 Addition Effects of Voltolized Whale \& Sperm Oils to Diesel Engine oils

\begin{tabular}{l|c|c|c|c}
\hline \multirow{2}{*}{ Sample } & \multicolumn{2}{|c|}{ Viscosity St. } & \multirow{2}{*}{ Viscosity Index } & Ponr Point ${ }^{\circ} \mathrm{C}$ \\
\cline { 2 - 4 } & $100^{\circ} \mathrm{F}$ & $210^{\circ} \mathrm{F}$ & 9.9 & -23 \\
\hline $\begin{array}{c}\text { Diesel Engine oil } \\
\text { ditto. added 10\% } \\
\text { with Voltolized Sperm oil }\end{array}$ & 151.6 & 9.9 & 70 & -21 \\
$\begin{array}{c}\text { ditto, added 10\% } \\
\text { with Voltolized Whale oil }\end{array}$ & 230.2 & 16.2 & 76 & -24 \\
\hline
\end{tabular}

It is known $^{56)}$ that the viscosity of such additives has a high dependency on shear rate and so with the last two samples listed in the same Table, the dependence of apparent viscosity on the shear rate was measured by Green type viscometer ${ }^{7)}$ in the range of about $0 \sim 1000$ $\sec ^{-1}$. In the case of non-addition, no shearing rate dependency was exhibited. In the case when additions were made, both samples attested to such dependency, and no large difference was observed between the two, as shown by Fig. 2 .

(Received January 19, 1959)

\section{Literature ;}

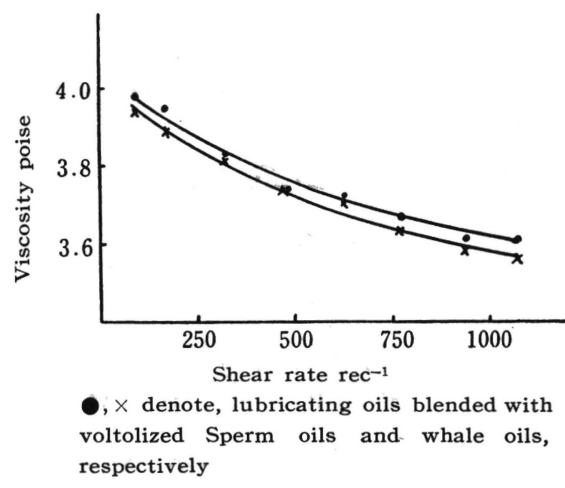

Fig. 2 Viscosity vs. rate of shear, for lubricating oils, blended with voltolized oils.

(Received January 19, 1959) 1)

1) Masao Gotoda, J. Electrochem. Soc. Japan, 27, 608 (1959).

2) Waichiro Tsuji, Studies on the plastisizers (Japan) 2, 21 (1950).

3) Koichi Murai, Rubber Digest (Japan) 9 (No. 6) 2 (1957).

4) H. Levin et al, Anal. Chem. 22, 188 (1950).

5) A. Bondi, Physical Chemistry of lubricating oils, p. 15 (1951).

6) W. Ostwald et al, Kolloid Z. 45, 166, 266 (1928).

7) H. Green, Industrial Rheology and Rheological Structure, p. 99 (1949). 